\title{
Effect of biostimulants on dry matter accumulation and gas exchange in plantain plants (Musa AAB)
}

\section{Efecto de bioestimulantes sobre la acumulación de materia seca e intercambio de gases en plantas de plátano (Musa AAB)}
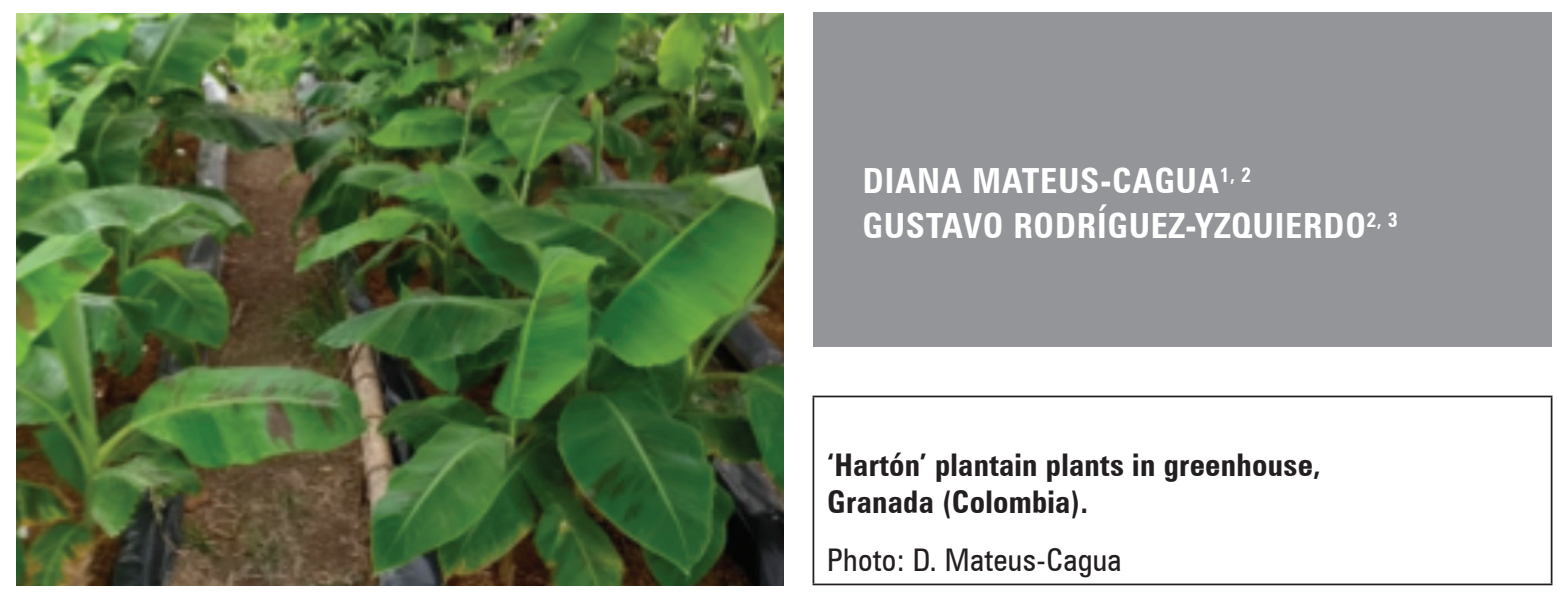

\section{ABSTRACT}

Biostimulants can potentially improve plant growth and development, modifying physiological processes. This study evaluated the effect of four biostimulants on the growth of 'Hartón' plantain plants and the leaf gas exchange during the vegetative phase. This experiment was developed on a plantain farm's nursery in Fuente de Oro (Colombia) with a randomized complete block design with four replicates. The treatments were the biostimulants: Bactox WP ${ }^{\circledR}$ : Bacillus subtilis (Bs); Baliente ${ }^{\circledR}$ : Bacillus amyloliquefaciens (Ba); Tierra Diatomeas ${ }^{\circledR}$ : silicon dioxide (Si); Re-Leaf ${ }^{\circledR}$ : salicylic acid (SA) and the control (water). All products had a positive effect on the accumulation of total dry matter (DM) (between 58.4 and 21.9\%) and on the photosynthetic activity (a maximum of 110 and $24.3 \%$ in first and second evaluation), as compared to the control, while no differences were found $(P>0.05)$ for the foliar emission rate and chlorophyll content between the treatments. The plants treated with $B s$ had the greatest DM accumulation at the end of the study and a constant, high photosynthetic activity. All the while $B s, B a$ and Si managed to stimulate greater early photosynthetic activity. According to the results, the use of these biostimulants during the vegetative phase had an effect on the physiological processes that enhance DM accumulation in plantain plants, which could be potentially useful for the transplanting stage and increase the reserves used during their establishment and development in the field.

\footnotetext{
Additional key words: photoassimilate distribution; 'Hartón' plantain; plant growth promoting rhizobacteria (PGPR); Bacillus; silicon; salicylic acid.

1 Universidad Nacional de Colombia, Faculty of Agricultural Sciences, Bogota; Corporación Colombiana de Investigación Agropecuaria (Agrosavia), C.I. La Libertad, Villavicencio (Colombia). ORCID Mateus-Cagua, D.M.: 0000-00017876-5343

2 Corporación Colombiana de Investigación Agropecuaria (Agrosavia), C.I. Tibaitata, Mosquera (Colombia). ORCID Rodríguez-Yzquierdo, G.: 0000-0003-3709-8534

3 Corresponding author. grodriguez@agrosavia.co
} 


\section{RESUMEN}

Los bioestimulantes son productos que potencialmente pueden mejorar el crecimiento y desarrollo de las plantas al modificar procesos fisiológicos. En este estudio se evaluó la influencia de cuatro bioestimulantes en el crecimiento de plantas de plátano 'Hartón' e intercambio de gases en un periodo de la fase vegetativa. El experimento se desarrolló en el vivero de una finca productora de plátano en Fuente de Oro (Colombia), en un diseño de bloques completos al azar generalizados con cuatro repeticiones. Los tratamientos correspondieron a los bioestimulantes Bactox WP ${ }^{\circledR}$ : Bacillus subtilis (Bs); Baliente ${ }^{\circledR}$ : Bacillus amyloliquefaciens (Ba); Tierras de diatomeas ${ }^{\circledR}$ : dióxido de silicio (Si); Re-Leaf ${ }^{\circledR}$ : ácido salicílico (As) y el control (agua). Todos los productos mostraron tener un efecto positivo en la acumulación de materia seca (MS) total (entre 58,4 y 21,9\%) y en la actividad fotosintética (en un máximo de 110 y $24,3 \%$ en primera y segunda evaluación) respecto al control, mientras que en ritmo de emisión foliar y contenido de clorofila no se encontraron diferencias $(P>0,05)$ entre tratamientos. Plantas tratadas con $B s$ tuvieron la mayor acumulación de MS al finalizar el estudio y una alta actividad fotosintética constante. Mientras que $B s, B a$ y $\mathrm{Si}$ lograron estimular una mayor actividad fotosintética temprana. De acuerdo con los resultados el uso de estos bioestimulantes durante esta fase vegetativa tiene efecto sobre procesos fisiológicos que mejoran la acumulación de MS en plantas de plátano, lo que podría capacitarlo para enfrentar la etapa de trasplante y aumentar las reservas para ser utilizadas durante su establecimiento y desarrollo en campo.

Palabras clave adicionales: distribución de fotoasimilados; plátano 'Hartón'; rizobacterias promotoras de crecimiento (PGPR); Bacillus; silicio; ácido salicílico.

Received for publication: 29-09-2018 Accepted for publication: 31-07-2019

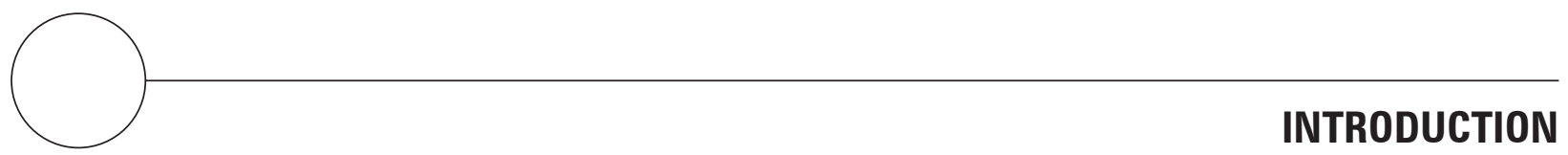

Biotic and abiotic factors affect crop production around the world. The presence of any of these can alter growth and development or completely interrupt the productive cycle, affecting physiological processes; for this reason, currently, strategies are being sought to prevent and minimize the risk of loss in production systems with a low investment, without affecting safety or quality (Halpern et al., 2015; Posmyk and Szafrańska, 2016). Several biostimulants have been evaluated and recommended as an alternative that prevents damage from these limitations, optimizing the growth of plants through different mechanisms (Saa et al., 2015; Wang et al., 2016; Magalhães et al., 2016), promoting quality and indirectly decreasing the use of agrochemicals (Yakhin et al., 2017).

According to du Jardin (2015), a plant biostimulant is any substance or microorganism applied to plants with the aim to enhance nutrition efficiency, abiotic stress tolerance and/or crop quality traits, regardless of its nutrients content. These substances can regulate physiological processes and perform directly on the metabolism, affecting development and productivity (Bulgari et al., 2015; Yakhin et al., 2017). Different categories of biostimulants have been proposed (Calvo et al., 2014); these include products containing hormones (Kauffman et al., 2007), inorganic compounds (such as Se y Si), and bacteria (mutualistic endosymbiont and plant growth-promoting rhizobacteria -PGPR-) (du Jardin, 2015), etc. Positive results have been found for different conditions and crops uses. Thus, silicon applications have been reported that improve plant growth and development under stress (Kurabachew and Wydra, 2014; AuciquePérez et al., 2017; Helaly et al., 2017) and non-stress conditions (Lavinsky et al., 2016). Likewise, PGPR applications have been shown to impact plant growth (Lavakush et al., 2014; Calvo et al., 2017), photosynthetic activity (Stefan et al., 2013), accumulation of dry matter, quality and yield of the final product (Mena-Violante and Olalde-Portugal, 2007; U1 Hassan and Bano, 2015).

Plantains and bananas are fruits crop with critical importance to global food security. The estimated annual global production exceeds 147 million $\mathrm{t}$ (FAOSTAT, 2016). However, these species are considered 
crops with high demand for agricultural inputs in order to obtain outstanding production and minimize risk from external factors, which in addition to being expensive may have an impact on the environment (Mia et al., 2010a). Biostimulants based on PGPR have been shown to enhance banana plant growth and nutrient uptake. Applications in a nursery can influence subsequent physiological stages, as well as in the final production, showing potential for use as an alternative in integrated management and cost reduction (Kavino et al., 2010; Mia et al., 2010a, 2010b). These reports indicate that the application of biostimulants (PGPR or another source) in the nursery phase could be useful for obtaining a greater accumulation of dry biomass for the critical stages of the species.

In this study, four biostimulants were evaluated: two PGPRs (Bacillus subtilis (Bs), Bacillus amyloliquefaciens $(B a)$ ), silicon dioxide (Si) and salicylic acid (As). The objective was to determinate their influence on growth variables and gas exchange in 'Hartón' plantain plants in the nursery phase. In this case, it was found that the use of these products promoted a greater accumulation of dry matter; furthermore, $B s$ and Si stimulated an early and higher photosynthetic rate, improving it significantly.

\section{MATERIALS AND METHODS}

This study was conducted in an outdoor nursery on a plantain production farm in Fuente de Oro, Meta (Colombia, 2017-2018) (3²5'39" N and 73 $37^{\prime} 12^{\prime \prime} \mathrm{W}$, altitude $307 \mathrm{~m}$ a.s.l.) from November to February. The climate of the region was tropical humid with an annual average rainfall of $2,621 \mathrm{~mm}$ (in a monomodal pattern) and a mean temperature of $25.6^{\circ} \mathrm{C}$. Plantain corms from cv. 'Hartón' (Musa AAB) were used from a farm with ICA registration to obtain the plant material. The whole corm technique was used for macropropagation (Njukwe et al., 2007; Buah and Tachie-Menson, 2015), which were established in wooden propagators for a month and a half. Then, shoots were carefully excised from the corm and transplanted as individual plantlets in $1.0 \times 7.0 \mathrm{~m}$ propagators containing rice husk. Each nursery bed was irrigated to maintain a $23 \pm 3 \%$ substrate moisture content; the plants were fertilized biweekly with a mixture of diammonium phosphate, urea, potassium chloride and micronutrients. This experiment was established in a randomized complete block design (simple factorial), with four repetitions and six plants per treatment. The treatments were the biostimulants (Bactox WP ${ }^{\circledR}$ : Bacillus subtilis (Bs); Baliente ${ }^{\circledR}$ : Bacillus amyloliquefaciens $(\mathrm{Ba})$; Tierra Diatomeas ${ }^{\circledR}$ : silicon dioxide (Si); Re-Leaf ${ }^{\circledR}$ : salicylic acid (SA)) and control (current volume of water). The products were applied based on the recommended doses: $5 \mathrm{~g} \mathrm{~L}^{-1}, 2.5$ and $1.25 \mathrm{cc} \mathrm{L}^{-1}$, and $4 \mathrm{~g} \mathrm{~L}^{-1}$ every 21 $\mathrm{d}$ from 0 to $12^{\text {th }}$ week. First, two biostimulants were applied as a substrate drench, SA by spraying the leaf tissue and by drenching and foliar spraying in the last two.

\section{'Hartón' plantain plantlet growth}

The pseudostem length was determined with a measuring tape, from the ground level to the insertion of the last leaf (youngest leaf); basal diameter was recorded with a Vernier caliper, and measured at $2 \mathrm{~cm}$ above the surface of the substrate. The foliar emission rate (FER) was determined by counting the number of fully expanded leaves emerged on each plant (Galán-Saúco and Robinson, 2013). These measurements were carried out in three plants per experiment unit every $15 \mathrm{~d}$.

At the end of the experiment, plants were carefully removed from the propagators, detached and weighed for the different organs (leaves, pseudostem, corm and roots). A sample of each one was taken to estimate the dry matter (DM) content. Likewise, the maximum root-length was measured with a tape measure. The collected plant samples were dried for $72 \mathrm{~h}$ in an oven at $65^{\circ} \mathrm{C}$, then the dry biomass was recorded.

\section{Gas exchange and SPAD units}

The leaf gas exchange were measured using a LI6400XT portable photosynthesis system (LICOR, Inc., Lincoln, NE), equipped with a LED light source (6400-02B). The assessments were taken between 9:00 and 11:30 am at a photosynthetic photon flux density of $300 \mu \mathrm{mol} \mathrm{m} \mathrm{m}^{-2} \mathrm{~s}^{-1}$ with a previous light saturation curve, while the $\mathrm{CO}_{2}$ concentration was adjusted to $400 \mu \mathrm{mol} \mathrm{m}{ }^{-2} \mathrm{~s}^{-1}$; the data were recorded when the coefficient of variation was less than $5 \%$. Parameters such as net photosynthesis rate (A), transpiration rate (Tr), stomatal conductance (Gs) and intercellular $\mathrm{CO}_{2}$ concentration $(\mathrm{Ci})$ were evaluated. The instantaneous carboxylation efficiency was calculated as ratio of A to $\mathrm{Ci}(\mathrm{A} / \mathrm{Ci})$. A portable chlorophyll meter (SPAD 502, Konica Minolta, Tokyo) was 
used to determinate the chlorophyll content based on the SPAD index. Data were collected from eight plants per treatment in the last four weeks, corresponding to $10^{\text {th }}$ through $12^{\text {th }}$ week; the third youngest fully expanded leaf (from the top) was measured for each plant (Galán-Saúco and Robinson, 2013).

\section{Statistical analysis}

A variance analysis followed by Tukey's multiple comparison test was carried out using statistical software R. Statistical significance at $P \leq 0.05$ was used to determine significant differences between the treatments. The data for length, diameter of pseudostem and number of emitted leaves were analyzed in a design with repeated measurements where time was considered the intra-subject factor. The means were determined with 12 plants per treatment in these variables.

\section{RESULTS}

The 'Hartón' plantain plantlets were treated with four commercial biostimulants for 12 weeks to identify their effect on physiological variables.

\section{Plantain plantlet growth}

There were no significant differences $(P>0.05)$ caused by the interaction (treatment and time) or treatments in the length, pseudostem diameter or number of emitted leaves, although there was effect of time from fourth week (Fig. 1). Despite the absence of differences caused by the treatments, there was a slight reduction in the increase of pseudostem length and diameter starting with the sixth week, mainly in the treatments $B a, B s$ and $\mathrm{Si}$; however, the trend was to increase (Fig. 1A and 1B). At the end of the experiment, the average length was $53.3 \mathrm{~cm}$, the pseudostem diameter was $4.23 \mathrm{~cm}$ and the number of emitted leaves was 12.73 (Fig. 1C). The mean FER was between 0.60 and 0.77 , with no differences between the treatments (Tab. 1).

All the plants submitted to treatment with biostimulants had a higher total DM accumulation than the control at 12 weeks after initiation of treatments (Tab. 1) although significant differences were found with Bs. The highest accumulation in the leaves, pseudostem, corm and root were stimulated with $B s$ while the control treatment maintained the lowest accumulation in the leaves, pseudostem and root. The maximum root length was achieved with the application of $B s$ and Si while As and $B a$ resulted in the lowest values. In general, the results suggested a positive effect from the biostimulants on the plantain plant growth.

Dry matter distribution between the plant organs; leaves had the greatest DM accumulation (percentage) during the vegetative phase in all treatments, followed by the pseudostem, corm and roots (Fig. 2).

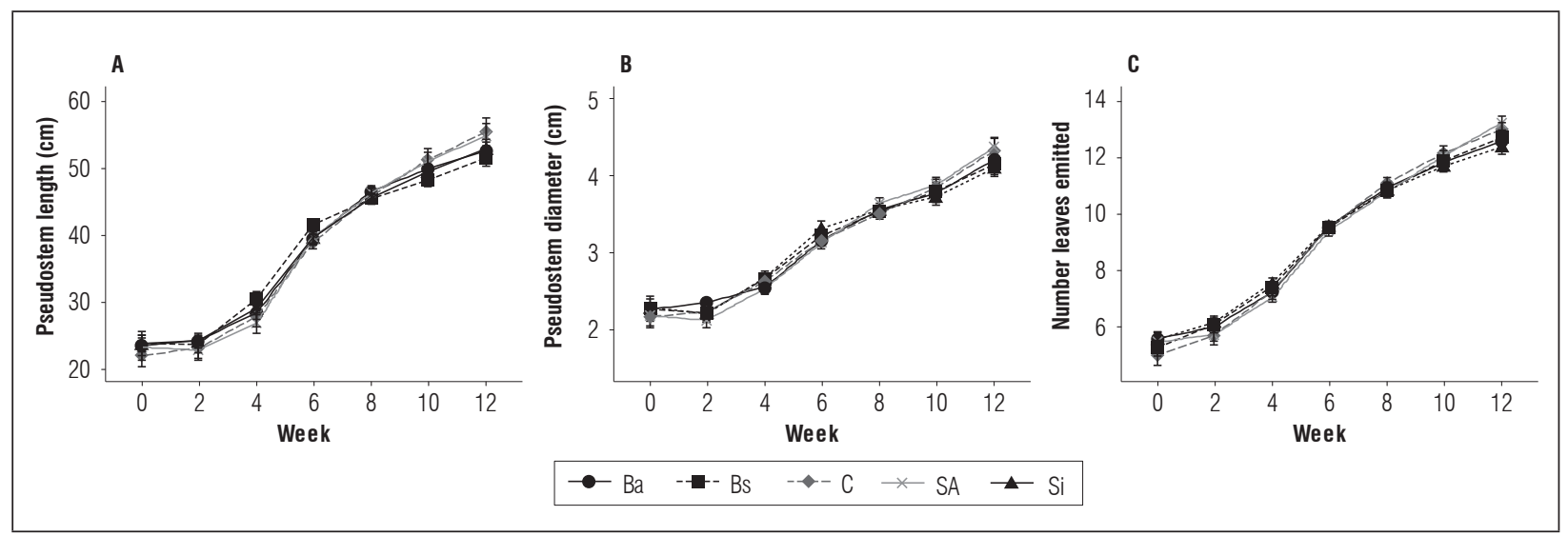

Figure 1. Pseudostem length $(A)$ and diameter (B); number of leaves (C) emitted in 'Hartón' plantain seedlings treated with biostimulant (Bs: B. subtilis, Si: silicon dioxide, SA: salicylic acid, C: control, Ba: B. amyloliquefaciens) in biweekly samplings from corm independence. Bars correspond to the standard error considering intra-subject variables $(n=12)$. 
Table 1. Influence of biostimulants on accumulation of dry matter, maximum root length and foliar emission rate (FER) of 'Hartón' plantain plants 12 weeks after detachment from the corms.

\begin{tabular}{|c|c|c|c|c|c|c|c|}
\hline \multirow{2}{*}{ Treatments } & \multicolumn{5}{|c|}{ Dry matter $(\mathrm{g})$} & \multirow{2}{*}{$\begin{array}{l}\text { Root length } \\
(\mathrm{cm})\end{array}$} & \multirow{2}{*}{ FER } \\
\hline & Leaves & Pseudostem & Corm & Root & Total & & \\
\hline Bs & $27.30 \mathrm{~b}$ & $18.92 \mathrm{~b}$ & $12.23 \mathrm{~b}$ & $6.26 \mathrm{~b}$ & $64.71 \mathrm{~b}$ & $50.05 b$ & $0.66 \mathrm{a}$ \\
\hline SA & $20.83 a b$ & $13.01 \mathrm{ab}$ & $9.85 a b$ & $6.23 b$ & $49.91 \mathrm{a}$ & $43.06 \mathrm{a}$ & $0.77 \mathrm{a}$ \\
\hline $\mathrm{Ba}$ & $20.58 a b$ & $17.57 \mathrm{a}$ & $8.90 \mathrm{a}$ & $4.88 a b$ & $51.92 \mathrm{ab}$ & $42.48 \mathrm{a}$ & $0.67 \mathrm{a}$ \\
\hline $\mathrm{Si}$ & $20.01 \mathrm{ab}$ & $18.04 \mathrm{a}$ & $9.59 \mathrm{ab}$ & $6.14 \mathrm{ab}$ & $53.78 \mathrm{ab}$ & $50.99 \mathrm{~b}$ & $0.60 \mathrm{a}$ \\
\hline C & $17.23 \mathrm{a}$ & 9.69 a & $9.30 \mathrm{a}$ & $4.74 \mathrm{a}$ & $40.95 \mathrm{a}$ & $44.69 a b$ & $0.72 \mathrm{a}$ \\
\hline
\end{tabular}

Means with different letters indicate significant differences after the Tukey test $(P \leq 0.05)(n=12)$. Bs, B. subtilis; As, salicylic acid; Ba, B. amyloliquefaciens; Si, silicon dioxide; $\mathrm{C}$, control.

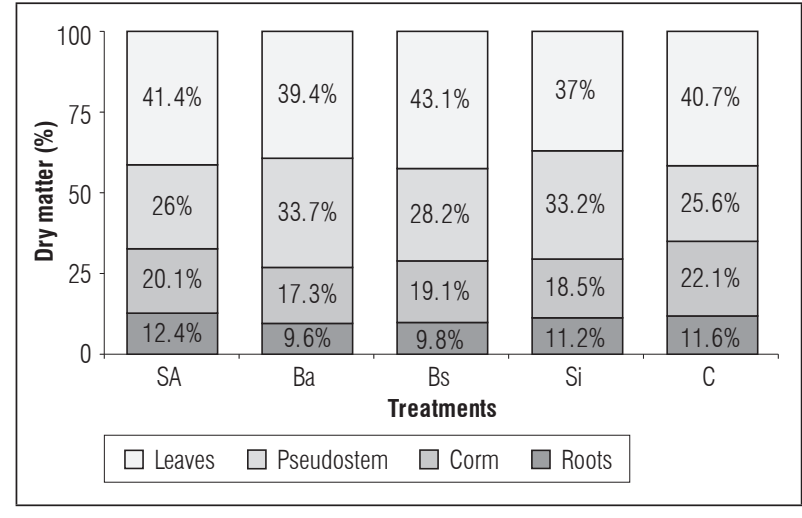

Figure 2. Dry matter distribution in 'Hartón' plantain plants 12 weeks after being independent from the corm. Bs: $B$. subtilis, Si: silicon dioxide, SA: salicylic acid, C: control (water), Ba: B. amyloliquefaciens.

\section{Photosynthetic activity}

Gas exchange variables were measured to validate the biostimulant effect on photosynthetic activity. The assessments were carried out at the $10^{\text {th }}$ and $12^{\text {th }}$ week (Fig. 3). The differences between the treatments were significant $(P \leq 0.05)$ for $\mathrm{A}$, Tr and carboxylation efficiency (Fig. 3). Three of the four biostimulants increased the net $\mathrm{CO}_{2}$ assimilation rate (A), as compared to the control: $B s, B a$ and $\mathrm{Si}$, while SA was in the same data range as the control plants. These three treatments had 110, 81 and $63 \%$ higher photosynthetic performance than the control in first evaluation. The results obtained with Gs and Tr had a similar trend. Bs induced the highest values at the first sampling (10 $10^{\text {th }}$ week) in A and Tr, resulting in a 2 -fold increase as compared to the control plants. For the subsequent evaluation (12 ${ }^{\text {th }}$ week), the difference between the non-treated, SA treated plants and the remaining treatments was reduced. Silicon dioxide reached the values of $B s$ in $\mathrm{A}$ and $\mathrm{A} / \mathrm{Ci}$; these two treatments had the highest values for the measured parameters, with a significant difference in $\mathrm{A} / \mathrm{Ci}$.

No significant differences were found in $\mathrm{Ci}$ between the treatments, while the instantaneous carboxylation efficiency had the same tendency as the photosynthetic rate, with significant differences. There were no differences in the chlorophyll content (SPAD index) between the treatments $(P>0.05)$; the average content was between 38.88 and 43.88 SPAD units in both the first and second evaluation (Fig. 3).

\section{DISCUSSION}

The use of biostimulants has been shown to promote growth in different plant species (Gemin et al., 2019; Saia et al., 2019; Agarwal et al., 2019). Musaceas such as plantains and banana plants require a high and fast dry matter accumulation and distribution to produce high-quality bunches (Turner, 1998; Chaves et al., 2009). Because these plants have a determinate growth, the development of the root system and leaves occurs during the vegetative phase and ceases with floral differentiation (Turner, 1998; Chaves et al., 2009). In this stage, the leaves, being the main source of assimilates, allocate part of the dry matter to form a strong pseudostem, while the corm is the main storage organ (Turner, 1998; Martínez and Cayón, 2011). Since stored photoassimilates can be remobilized in the next phases, an adequate dry matter accumulation at this phase could improve the source-sink relationship. The results revealed that the $B s, \mathrm{Si}, \mathrm{Ba}$ and SA applications increased the total dry matter accumulation in the 'Hartón' plantain plants, with values of 58.3, 31.3, 26.8 and $21.9 \%$, 


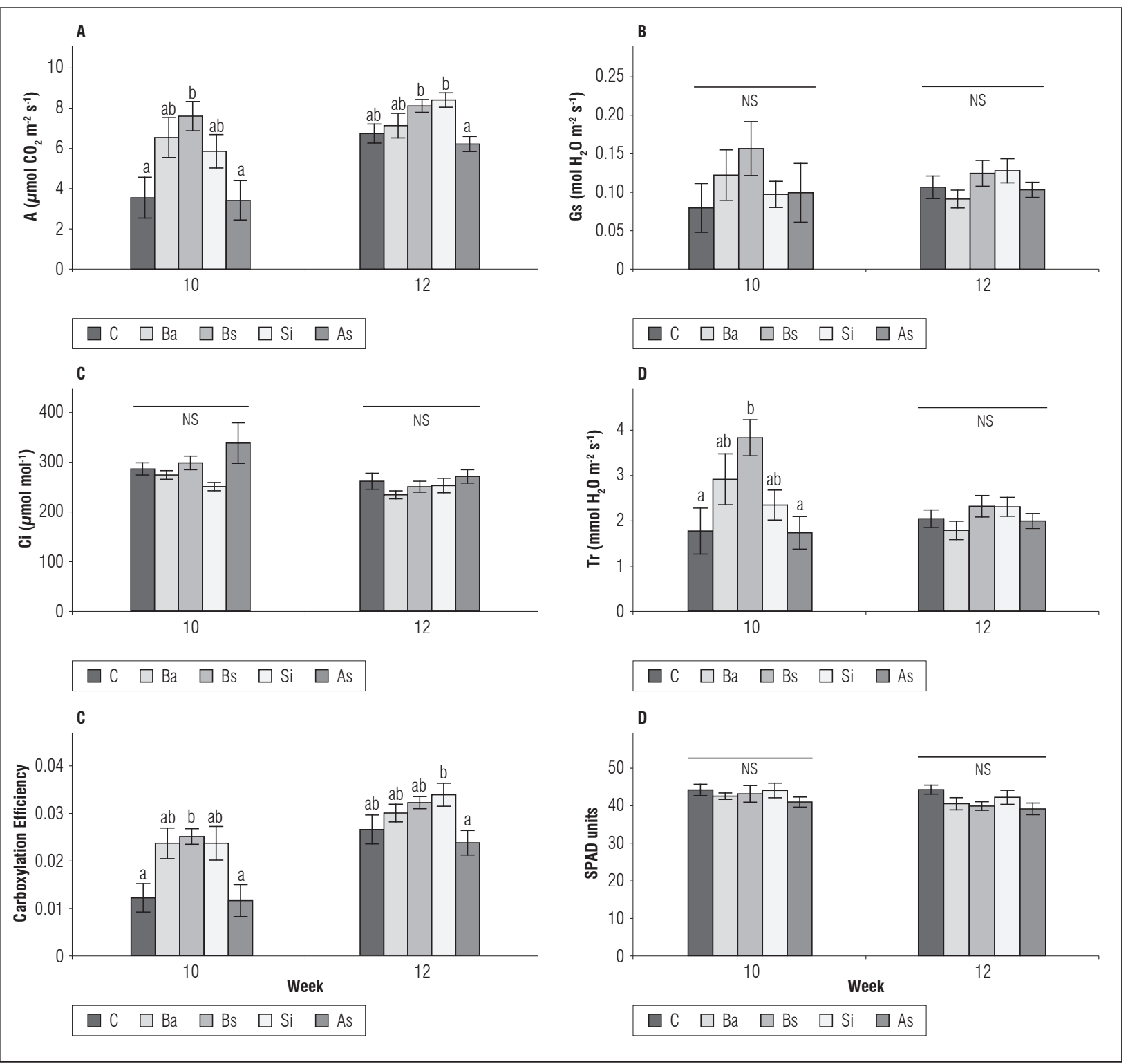

Figure 3. Influence of biostimulants on parameters of gas exchange in 'Hartón' plantain plants, 10 and 12 weeks after being independent of the corm. A: photosynthesis; Gs: stomatal conductance; $\mathrm{Ci}$ : intercellular $\mathrm{CO}_{2}$ concentration; Tr: transpiration; carboxylation efficiency $(\mathrm{A} / \mathrm{Ci}): \mu \mathrm{mol} \mathrm{m} \mathrm{m}^{-2} \mathrm{~s}^{-1}$; NS: not significant. Bars correspond to the standard error. Means with different letters per week of evaluation indicate significant differences between treatments after the Tukey test $(P \leq 0.05)(n=8)$. Bs: $B$. subtilis, Si: silicon dioxide, SA: salicylic acid, C: control, Ba: B. amyloliquefaciens.

respectively, as compared with the control plants during the vegetative phase. Although this improvement occurred through different modes of action, the results indicated that these mechanisms directly or indirectly improved the photosynthetic activity, as can be observed with $B s, B a$ and Si (Fig. 3).

B. subtilis was the treatment $(B s)$ that induced the highest response of biomass production and photosynthetic activity in the vegetative period. This PGPR has been reported as promoting DM accumulation through direct mechanisms: phytohormone production such as auxins and gibberellins (involved in processes such as cell elongation and division) and enhancing plant nutrient absorption (Mohamed and Gomaa, 2012; Ahmad et al., 2017; Jang et al., 2018). In addition, $B s$ has been shown to increase photosynthetic efficiency, chlorophyll content and sugar 
accumulation in several studies (Zhang et al., 2008; Ul Hassan and Bano, 2015). According to Zhang et al. (2008), Bs can repress hexokinase-dependent glucose signaling (HXK), which limits the photosynthetic inhibition induced by the end-product and stimulates photosynthetic activity. The high activity found in this experiment was accompanied by an increase in Gs at the $10^{\text {th }}$ week (Fig. 3), which coincided with the reports of Zhang et al. (2008) and Mahomed and Gomaa (2012), who stated that Bs mediates the reduction of abscisic acid levels, the hormone involved in stomatal closure. Bs could promote an increase in endogenous hormones, improving the efficiency of nutrient acquisition, with better root growth evidenced in DM accumulation (Tab. 1) and an increase in the photosynthetic rate (Fig. 3), which would explain the outstanding feature.

The plants treated with $B$. amyloliquefaciens $(B a)$ showed an intermediate behavior in both $\mathrm{A}$ and $\mathrm{DM}$ accumulation. In comparison with $B s$ (also a PGPR), $\mathrm{Ba}$ stimulated leaf and pseudostem growth more than root growth although the pseudostem length and diameter (Fig. 1) were similar, suggesting its effect as a growth promoter, which could be related to its action on the hormonal balance as reported by Asari et al. (2017). That promotion was also observed in the evaluation of the photosynthetic activity. The treatments did not show differences in the chlorophyll content (SPAD index); the data were similar to reports for Musaceae (Hooks et al., 2008; Anusuya, 2014).

The effects of exogenous applications of SA on the physiological processes of plants, on the other hand, are controversial. Some studies have reported better growth, photosynthetic activity and photosynthetic pigment contents with its use in stressed plants (Jalal et al., 2012; Nazar et al., 2015; Cao et al., 2015; Elhakem, 2019), while other research results have indicated a negative effect on these parameters (Mancheva et al., 1996). Therefore, these assays suggest that there is a species-specific response and a relationship with the applied proportion (Janda et al., 2014). In this study, the SA application enhanced the dry matter accumulation of the 'Hartón' plantain plants in comparison with the control plants (although without statistical differences) by a different mechanism that increased photosynthetic activity (Fig. 3).

Silicon has been the subject of multiple studies. Its main positive effect has been found in alleviating biotic or abiotic stress (Zanetti et al., 2016; Maghsoudi et al., 2016a). However, under the non-stress conditions of the present study, the results showed that $\mathrm{Si}$ induced a higher photosynthetic rate than the control plants on the two evaluation dates although there was a statistical difference. Similar results were reported for wheat, corn, and rice by Maghsoudi et al. (2016b), Xie et al. (2014), and Detmann et al. (2012), respectively. The stimulated photosynthetic activity could be related to the stability in the Tr values because, despite increases in Gs between the first and second evaluation, the $\operatorname{Tr}$ rates remained constant and the water use efficiency improved (data not shown). This response could be related to Si deposition mainly in epidermal cells, which would maintain transpiration and plant water potential, as has been reported for rice and corn (Agarie et al., 1998; Gao et al., 2006). The carboxylation efficiency was greater in the Si treated plants than in the control, suggesting a higher $\mathrm{CO}_{2}$ fixation as a result of the increase in Gs; the total DM accumulation was also superior to the control plants, especially at the leaf and pseudostem level. In addition, according to $\mathrm{Xu}$ et al. (2016), an increase in photosynthesis without differences in $\mathrm{Ci}$ (between the first and second evaluation) could suggest that $\mathrm{Si}$ has an effect on stomatal and non-stomatal factors, as has been reported in rice plants subjected to stress, in which an Si application increased the transcription of genes involved in photosystem efficiency and electron transport chain (Song et al., 2014).

In banana, Mia et al. (2010b) reported than PGPR applications, in combination with fertilizer-N (after transplant to hydroponic system), significantly increased root growth, total biomass, photosynthetic rate and bunch yield. Similarly, the use of bio-formulations containing PGPR in different stages of the productive cycle improved plant biometric parameters and had a cumulative effect on yield and fruit quality attributes (Kavino et al., 2010). On the other hand, the effect of hormones and inorganic compounds (such as SA and $\mathrm{Si}$ ) on musaceas plants has been researched mainly with a phytopathological approach.

According to the background and results obtained in the vegetative phase, it could be expected that the use of the evaluated biostimulants ( $B s$ and $\mathrm{Si}$ ) has a potential effect on subsequent phases of the productive cycle since they improved growth (DM accumulation) through various mechanisms. Therefore, these products could be an important technological alternative in integrated plantain management. Additionally, their active ingredients have been reported 
to reduce the disease symptoms caused by Ralstonia solanacearum in different species. Since it is one of the most important production-limiting diseases in the plantain crop system throughout the domestic production area, it would be important to determine their influence on disease progression.

\section{CONCLUSIONS}

All biostimulants applied in the evaluated vegetative phase stimulated a greater DM accumulation than in the control through different mechanisms (in a range between 58.3 and $21.9 \%$ ) although only the $B s$ treatment had a significant difference. This DM was assigned mainly to the leaves and pseudostem, indicating the formation of a strong structure that will physically support production and will serve as storage for the reproductive and productive phases. On the other hand, $B s, B a$ and $\mathrm{Si}$ stood out because of their outstanding action on the early photosynthetic activity and DM accumulation, showing potential for evaluation under field conditions.

\section{ACKNOWLEDGMENTS}

The authors express their gratitude to Tatiana Miranda, Sandra Alzate and Pedro García for their support in the administrative and field activities, to researcher Nubia Rodríguez for her advice on the equipment used and methodological suggestions, and to Agrosavia for financing the project "Model - Efficient technologies for the production of banana seeds in Colombia (ID:860-2018)".

Conflict of interests: this manuscript was prepared and reviewed with the participation of the authors, who declare that there exists no conflict of interest that puts the validity of the presented results at risk.

\section{BIBLIOGRAPHIC REFERENCES}

Agarie, S., H. Uchida, W. Agata, F. Kubota, and P.B. Kaufman. 1998. Effects of silicon on transpiration and leaf conductance in rice plants (Oryza sativa $\mathrm{L}$ ). Plant Prod. Sci. 1(2), 89-95. Doi: 10.1626/pps.1.89

Agarwal, P., P.C. Singh, V. Chaudhry, P.A. Shirke, D. Chakrabarty, A. Farooqui, C.S. Nautiyal, A.P. Sane, and V.A. Sane. 2019. PGPR-induced OsASR6 improves plant growth and yield by altering root auxin sensitivity and the xylem structure in transgenic Arabidopsis thaliana. J. Plant Physiol. 240, 153010. Doi: 10.1016/j. jplph.2019.153010

Ahmad, Z., J. Wu, L. Chen, and W. Dong. 2017. Isolated Bacillus subtilis strain 330-2 and its antagonistic genes identified by the removing PCR. Sci. Rep. 7, 1777. Doi: 10.1038/s41598-017-01940-9

Anusuya, P. 2014. Studies on screening of banana genotypes against salt and water deficit stresses. $\mathrm{PhD}$ thesis. Tamil Nadu Agricultural University, Coimbatore, India.

Asari, S., D. Tarkowská, J. Rolčík, O. Novák, D.V. Palmero, S. Bejai, and J. Meijer. 2017. Analysis of plant growth-promoting properties of Bacillus amyloliquefaciens UCMB5113 using Arabidopsis thaliana as host plant. Planta 245(1), 15-30. Doi: 10.1007/s00425-016-2580-9

Aucique-Pérez, C.E., P.E. Menezes Silva, W.R. Moreira, F.M. DaMatta, and F.Á. Rodrigues. 2017. Photosynthesis impairments and excitation energy dissipation on wheat plants supplied with silicon and infected with Pyricularia oryzae. Plant Physiol. Biochem. 121, 196205. Doi: 10.1016/j.plaphy.2017.10.023

Buah, J.N. and J.W. Tachie-Menson. 2015. Suitability of bud manipulation technique as an alternative to tissue culture in the production of suckers for plantains and bananas. Biotechnol. 14(1), 41-46. Doi: 10.3923/ biotech.2015.41.46

Bulgari, R., G. Cocetta, A. Trivellini, P. Vernieri, and A. Ferrante. 2015. Biostimulants and crop responses: a review. Biol. Agric. Hort. 31(1), 1-17. Doi: 10.1080/01448765.2014.964649

Calvo, P., L. Nelson, and J.W. Kloepper. 2014. Agricultural uses of plant biostimulants. Plant Soil 383(1-2), 3-41. Doi: $10.1007 / \mathrm{s} 11104-014-2131-8$

Calvo, P., D.B. Watts, J.W. Kloepper, and H.A. Torbert. 2017. Effect of microbial-based inoculants on nutrient concentrations and early root morphology of corn (Zea mays). J. Plant Nutr. Soil Sci. 180(1), 56-70. Doi: 10.1002/jpln.201500616

Cao, W.L., X.C. Meng, and W. Ma. 2015. Effect of salicylic acid on photosynthesis, physio-biochemistry and quality of Panax ginseng under full sun shine in spring. China J. Chin. Materia Med. 40(18), 3553-3559. Doi: 10.4268/cjcmm20151808

Chaves, B., G. Cayón, and J.W. Jones. 2009. Modeling plantain (Musa AAB Simmonds) potential yield. Agron. Colomb. 27(3), 359-366.

Detmann, K.C., W.L. Araújo, S.C.V. Martins, L.M.V.P. Sanglard, J.V. Reis, E. Detmann, F.Á. Rodrigues, A. Nunes-Nesi, A.R. Fernie, and F.M. DaMatta. 2012. Silicon nutrition increases grain yield, which, in turn, exerts a feed-forward stimulation of photosynthetic rates via enhanced mesophyll conductance and alters primary 
metabolism in rice. New Phytologist 196(3), 752-762. Doi: 10.1111/j.1469-8137.2012.04299.x

Du Jardin, P. 2015. Plant biostimulants: definition, concept, main categories and regulation. Sci. Hortic. 196, 3-14. Doi: 10.1016/j.scienta.2015.09.021

Elhakem, A.H. 2019. Impact of salicylic acid application on growth, photosynthetic pigments and organic osmolytes response in Mentha arvensis under drought stress. J. Biol. Sci. 19(6), 372-380. Doi: 10.3923/ jbs.2019.372.380

FAOSTAT. 2016. Agriculture data. In: http://www.fao.org/ faostat/en/\#data/QC; consulted: Mach, 2018.

Galán-Saúco, V. and J. C. Robinson. 2013. Fisiología, clima y producción de banano. pp. 44-56. In: XX Reunião Internacional da Associação para a Cooperação em Pesquisa e Desenvolvimento Integral das Musáceas (Bananas e Plátanos). Fortaleza, Brazil.

Gao, X., C. Zou, L. Wang, and F. Zhang. 2006. Silicon decreases transpiration rate and conductance from stomata of maize plants. J. Plant Nutr. 29(9), 1637-1647. Doi: 10.1080/01904160600851494

Gemin, L.G., Á.F. Mógor, J.D.O. Amatussi, and G. Mógor. 2019. Microalgae associated to humic acid as a novel biostimulant improving onion growth and yield. Sci. Hortic. 256, 108560. Doi: 10.1016/j. scienta.2019.108560

Halpern, M., A. Bar-Tal, M. Ofek, D. Minz, T. Müller, and U. Yermiyahu. 2015. The use of biostimulants for enhancing nutrient uptake. Adv. Agron. 130, 141-174. Doi: 10.1016/bs.agron.2014.10.001

Helaly, M.N., H. El-Hoseiny, N.I. El-Sheery, A. Rastogi, and H.M. Kalaji. 2017. Regulation and physiological role of silicon in alleviating drought stress of mango. Plant Physiol. Biochem. 118, 31-44. Doi: 10.1016/j. plaphy.2017.05.021

Hooks, C.R.R., M.G. Wright, D.S. Kabasawa, R. Manandhar, and R.P.P. Almeida. 2008. Effect of banana bunchy top virus infection on morphology and growth characteristics of banana. Ann. Appl. Biol. 153(1), 1-9. Doi: 10.1111/j.1744-7348.2008.00233.x

Jalal, R.S., S.O. Bafeel, and A.E. Moftah. 2012. Effect of salicylic acid on growth, photosynthetic pigments and essential oil components of Shara (Plectranthus tenuiflorus) plants grown under drought stress conditions. Int. Res. J. Agric. Sci. Soil Sci. 2(6), 252-260.

Janda, T., O.K. Gondor, R. Yordanova, G. Szalai, and M. Pál. 2014. Salicylic acid and photosynthesis: signalling and effects. Acta Physiol. Plant. 36(10), 2537-2546. Doi: 10.1007/s11738-014-1620-y

Jang, J.H., S.-H. Kim, I. Khaine, M.J. Kwak, H.K. Lee, T.Y. Lee, W.Y. Lee, and S.Y. Woo. 2018. Physiological changes and growth promotion induced in poplar seedlings by the plant growth-promoting rhizobacteria Bacillus subtilis JS. Photosynthetica 56(4), 1188-1203. Doi: 10.1007/s11099-018-0801-0

Kauffman, G.L., D.P. Kneivel, and T.L. Watschke. 2007. Effects of a biostimulant on the heat tolerance associated with photosynthetic capacity, membrane thermostability, and polyphenol production of perennial ryegrass. Crop Sci. 47(1), 261-267. Doi: 10.2135/ cropsci2006.03.0171

Kavino, M., S. Harish, N. Kumar, D. Saravanakumar, and R. Samiyappan. 2010. Effect of chitinolytic PGPR on growth, yield and physiological attributes of banana (Musa sp) under field conditions. Appl. Soil Ecol. 45(2), 71-77. Doi: 10.1016/j.apsoil.2010.02.003

Kurabachew, H. and K. Wydra. 2014. Induction of systemic resistance and defense-related enzymes after elicitation of resistance by rhizobacteria and silicon application against Ralstonia solanacearum in tomato (Solanum lycopersicum). Crop Prot. 57, 1-7. Doi: 10.1016/j.cropro.2013.10.021

Lavakush, J. Yadav, J.P. Verma, D.K. Jaiswal, and A. Kumar. 2014. Evaluation of PGPR and different concentration of phosphorus level on plant growth, yield and nutrient content of rice (Oryza sativa). Ecol. Eng. 62, 123128. Doi: 10.1016/j.ecoleng.2013.10.013

Lavinsky, A.O., K.C. Detmann, J.V. Reis, R.T. Ávila, M.L. Sanglard, L.F. Pereira, L.M.V.P. Sanglard, F.A. Rodrigues, W.L. Araújo, and F.M. DaMatta. 2016. Silicon improves rice grain yield and photosynthesis specifically when supplied during the reproductive growth stage. J. Plant Physiol. 206, 125-132. Doi: 10.1016/j. jplph.2016.09.010

Magalhães, J.E.S., E.A. Ferreira, M.C. Oliveira, G.A.M. Pereira, D.V. Silva, and J.B Santos. 2016. Effect of plantbiostimulant on cassava initial growth. Rev. Ceres 63(2), 208-213. Doi: 10.1590/0034-737X201663020012

Maghsoudi, K., Y. Emam, and M. Ashraf. 2016a. Foliar application of silicon at different growth stages alters growth and yield of selected wheat cultivars. J. Plant Nutr. 39(8), 1194-1203. Doi: 10.1080/01904167.2015.1115876

Maghsoudi, K., Y. Emam, and M. Pessarakli. 2016b. Effect of silicon on photosynthetic gas exchange, photosynthetic pigments, cell membrane stability and relative water content of different wheat cultivars under drought stress conditions. J. Plant Nutr. 39(7), 10011015. Doi: 10.1080/01904167.2015.1109108

Martínez, A.M. and D.G. Cayón. 2011. Dinámica del crecimiento y desarrollo del banano (Musa AAA Simmonds cvs. Gran Enano y Valery). Rev. Fac. Nac. Agron. Medellín 64(2), 6055-6064.

Mena-Violante, H.G. and V. Olalde-Portugal. 2007. Alteration of tomato fruit quality by root inoculation with plant growth-promoting rhizobacteria (PGPR): $B a-$ cillus subtilis BEB-13bs. Sci. Hortic. 113(1), 103-106. Doi: 10.1016/j.scienta.2007.01.031 
Mia, M.A.B., Z.H. Shamsuddin, and M. Mahmood. 2010a. Use of plant growth promoting bacteria in banana: a new insight for sustainable banana production. Int. J. Agric. Biol. 12(3), 459-467.

Mia, M.A.B., Z.H. Shamsuddin, Z. Wahab, and M. Marziah. 2010b. Rhizobacteria as bioenhancer and biofertilizer for growth and yield of banana (Musa spp. cv. 'Berangan'). Sci. Hortic. 126(2), 80-87. Doi: 10.1016/j. scienta.2010.06.005

Mohamed, H.I. and E.Z. Gomaa. 2012. Effect of plant growth promoting Bacillus subtilis and Pseudomonas fluorescens on growth and pigment composition of radish plants (Raphanus sativus) under $\mathrm{NaCl}$ stress. Photosynthetica 50(2), 263-272. Doi: 10.1007/ s11099-012-0032-8

Nazar, R., S. Umar, and N.A. Khan. 2015. Exogenous salicylic acid improves photosynthesis and growth through increase in ascorbate-glutathione metabolism and $\mathrm{S}$ assimilation in mustard under salt stress. Plant Signal. Behav. 10(3), e1003751. Doi: 10.1080/15592324.2014.1003751

Njukwe, E., A. Tenkouano, D. Amah, K. Sadik, M. Pérez, M. Nyine, and T. Dubois. 2007. Macro-propagation of banana and plantain: training manual. International Institute of Tropical Agriculture (IITA), Ibadan, Nigeria.

Posmyk, M.M. and K. Szafrańska. 2016. Biostimulators: a new trend towards solving an old problem. Front. Plant Sci. 7, 748. Doi: 10.3389/fpls.2016.00748

Saa, S., A. Olivos-Del Rio, S. Castro, and P.H. Brown. 2015. Foliar application of microbial and plant based biostimulants increases growth and potassium uptake in almond (Prunus dulcis [Mill.] DA Webb). Front. Plant Sci. 6, 87. Doi: 10.3389/fpls.2015.00087

Saia, S., G. Colla, G. Raimondi, E. Di Stasio, M. Cardare1li, P. Bonini, P. Vitaglione, S. De Pascale, and Y. Rouphael. 2019. An endophytic fungi-based biostimulant modulated lettuce yield, physiological and functional quality responses to both moderate and severe water limitation. Sci. Hortic. 256, 108595. Doi: 10.1016/j. scienta.2019.108595

Song, A., P. Li, F. Fan, Z. Li, and Y. Liang. 2014. The effect of silicon on photosynthesis and expression of its relevant genes in rice (Oryza sativa L.) under high-zinc stress. PLoS ONE 9(11), e113782. Doi: 10.1371/journal.pone.0113782

Stefan, M., N. Munteanu, V. Stoleru, M. Mihasan, and L. Hritcu. 2013. Seed inoculation with plant growth promoting rhizobacteria enhances photosynthesis and yield of runner bean (Phaseolus coccineus L.). Sci. Hortic. 151, 22-29. Doi: 10.1016/j.scienta.2012.12.006

Turner, D.W. 1998. Ecophysiology of bananas: the generation and functioning of the leaf canopy. Acta Hortic. 490, 211-222. Doi: 10.17660/ActaHortic.1998.490.21

Ul Hassan, T. and A. Bano. 2015. The stimulatory effects of L-tryptophan and plant growth promoting rhizobacteria (PGPR) on soil health and physiology of wheat. J. Soil Sci. Plant Nutr. 15(1), 190-201. Doi: 10.4067/ S0718-95162015005000016

Wang, Q., I.C. Dodd, A.A. Belimov, and F. Jiang. 2016. Rhizosphere bacteria containing 1-aminocyclopropane-1-carboxylate deaminase increase growth and photosynthesis of pea plants under salt stress by limiting $\mathrm{Na}^{+}$accumulation. Funct. Plant Biol. 43(2), 161-172. Doi: 10.1071/FP15200

Xie, Z., F. Song, H. Xu, H. Shao, and R. Song. 2014. Effects of silicon on photosynthetic characteristics of maize (Zea mays L.) on alluvial soil. Sci. World J. 2014, 718716. Doi: 10.1155/2014/718716

Xu, H., Y. Lu, and Z. Xie. 2016. Effects of silicon on maize photosynthesis and grain yield in black soils. Emir. J. Food Agr. 28(11), 779-785. Doi: 10.9755/ ejfa.2016-06-730

Yakhin, O.I., A.A. Lubyanov, I.A. Yakhin, and P.H. Brown. 2017. Biostimulants in plant science: a global perspective. Front. Plant Sci. 7, 2049. Doi: 10.3389/ fpls.2016.02049

Zanetti, L.V., C.R.D. Milanez, V.N. Gama, M.A.G. Aguilar, C.A.S. Souza, E. Campostrini, T.M. Ferraz, and F.A.M.M.A. Figueiredo. 2016. Leaf application of silicon in young cacao plants subjected to water deficit. Pesq. Agropec. Bras. 51(3), 215-223. Doi: 10.1590/ S0100-204X2016000300003

Zhang, H., X. Xie, M.S. Kim, D.A. Kornyeyev, S. Holaday, and P.W. Paré. 2008. Soil bacteria augment Arabidopsis photosynthesis by decreasing glucose sensing and abscisic acid levels in planta. Plant J. 56(2), 264-273. Doi: 10.1111/j.1365-313X.2008.03593.x 